\title{
Tutkimuksia salaatin, tomaatin ja porkkanan sisäisestä laadusta markkinoinnin aikana
}

\author{
Taina Kuusi, Tuija Virtanen ja Kaija Kleemola \\ Elintarvikelaboratorio, Valtion teknillinen tutkimuskeskus, 02150 Espoo 15
}

\author{
Studies on the intrinsic quality of lettuce, tomatoes and carrots \\ during marketing
}

\author{
Taina KuUsi, Tuija Virtanen and Kaija Kleemola \\ Food Research Laboratory, Technical Research Centre of Finland, SF-02150 Espoo 15, Finland
}

\begin{abstract}
The intrinsic quality of vegetables depends on their sensory properties and nutritional value, and on safety factors. In the present study, some methods suitable for the characterization of the intrinsic quality were investigated in regard to practicability. These methods were used to evaluate the quality of vegetables on the market.

Three vegetables were studied: lettuce, tomato and carrot. Samples were obtained from wholesale dealers; some samples were bought from the open market. The material was mainly home-grown, but some samples were imported.

The main series comprised wholesale samples of all three vegetables, six times throughout the year. In addition, tomato samples from the open market at different price levels were studied. Storage experiments were performed with lettuce and tomatoes. Quality was evaluated by sensory means (scoring method), the properties studied being taste, smell, structure and appearance. In addition, the quality grade was evaluated.

Analytical criteria were soluble solids, acid content, ascorbic acid and nitrate content, and sometimes weight and trimming losses.

Sensory evaluation was best for the characterization of the intrinsic quality. Mostly, the official classification agreed well with the sensory properties, but sometimes a bitter taste or some other off-taste was observed. In the nitrate content great variations were found, but these were unrelated to the quality class. The other methods were less suitable as they are influenced by very many factors. The methods tested may be useful in the development of better market vegetables.
\end{abstract}

\section{Johdanto}

Kasviksien laadun karakterisoinnissa käytetään tavallisesti ulkoisia ominaisuuksia, kuten kokoa, muotoa, virheettömyyttä jne. Tällaisten kriteerien perusteella on useimmiten myös rajattu toisistaan eri laatuluokat. Koska 
nämä ominaisuudet eivät aina anna riittäviä takeita laadusta, on viime aikoina alettu kiinnittää huomiota myös ns. sisäiseen laatuun, joka sisältyy osana kokonaislaatuun. Se mitä sisäiseen laatuun kuuluu, ei vielä ole täysin yksikäsitteisesti määritelty. Eräitä tärkeimpiä sisäisiä laadun tekijöitä ovat aistinvaraisesti todettavat ominaisuudet, erityisesti maku, haju ja rakenne. Ulkonäkö on myöskin yksi aistinvaraisesti todettavista ominaisuuksista, vaikka se toisaalta kuuluu myös ulkoiseen laatuun ja laatuluokitukseen. Sisäiseen laatuun kuuluvat lisäksi ravitsemukselliset ominaisuudet, kuten yleinen koostumus ja erityisesti vitamiinien ja kivennäisaineiden määrät. Edelleen se, missä määrin kasvikset ovat vapaita mahdollisista haittatekijöistä, kuten nitraatin ja muiden lannoitteiden jäämistä, raskasmetalleista ja torjuntaaineista, on sisäisen laadun kriteeri. Sisäistä laatua tai biologista arvoa on erityisesti selvitellyt Schuphan koulukuntineen (mm. Hentschel ja Schuphan, 1975). KRAMER (1962) on esittänyt kaavion elintarvikkeiden eri laatutekijöiden luokittelusta.

Kasviksien kaupassa ei sisäistä laatua ole tähän asti voitu kovin paljon ottaa huomioon. Suomessa on äskettäin ollut toiminnassa työryhmä, jonka puitteissa on keskusteltu mahdollisuuksista sisäisen laadun tekijöiden deklaroimiseksi kasviksien kaupassa. Deklarointi edellyttäisi sitä, että nämä laatutekijät voitaisiin myös mitata eksaktein menetelmin. Tämä taas edellyttäisi tarkoitukseen soveltuvia menetelmiä, joiden tulisi käytännön vaatimusten vuoksi olla mahdollisimman yksinkertaisia.

Tässä tutkimuksessa on pyritty selvittämään mahdollisuuksia kaupan kasviksien sisäisen laadun karakterisoimiseksi käyttäen malliesimerkkeinä kolmea markkinoilla runsaasti myytyä kasvista, salaattia, tomaattia ja porkkanaa. Tutkimuksessa on tarkoituksellisesti käytetty sisäisen laadun kriteereinä sellaisia ominaisuuksia, joille on käytettävissä suhteellisen yksinkertaisia menetelmiä. Tästä syystä on kriteereistä jätetty pois sellaiset kuin raskasmetallit ja torjunta-aineet, joiden analyysit pakostakin ovat hitaita, vaivalloisia ja kalliita. Tutkimuksella toivottiin saatavan tietoa siitä, miten hyvin sisäistä laatua voidaan arvioida käyttäen eräitä yksinkertaisia analyysimenetelmiä sekä aistinvaraista arvostelua.

\section{Materiaali ja menetelmät}

Tutkimuskohteiksi valittiin kolme yleisesti markkinoilla esiintyvää kasvista: salaatti, jonka säilyvyysaika on lyhyt, tomaatti, jonka säilyvyysaika on keskipitkä, ja porkkana, jonka säilyvyysaika on pitkä. Kustakin kasviksesta saatiin näytteitä läpi koko vuoden: kesäkuussa, elokuussa, syyskuussa, marraskuussa, helmikuussa sekä huhti-toukokuussa. Näytteiden toimittajina oli neljä kaupan yleistukkuliikettä sekä yksi puutarhatuotteisiin erikoistunut tukkuliike. Yleensä näytteet saatiin siinä vaiheessa, kun ne olivat saapuneet tukkuliikkeen vastaanottoon ja kukin näyte edusti yhtä tukkukaupan pakkausta (tomaatilla $5 \mathrm{~kg}$, porkkanalla 5-10 $\mathrm{kg}$ ja salaatilla $2-4$ (6) kg; joissakin tapauksissa näytteet olivat vähittäiskauppapakkauksissa. 
Näytteet olivat kulloinkin ko. liikkeen senhetkistä valtalajiketta. Huhtikuussa hankittiin tomaatti- ja salaattinäytteitä poikkeuksellisesti sellaisista vähittäiskaupoista, joihin ko. tukkuliikkeet toimittavat näitä kasviksia. Näytteet olivat pääasiallisesti kotimaisia, mutta salaatti oli helmikuussa ulkomaista, tomaattinäytteet taas olivat helmikuussa pelkästään ja marrasja huhtikuussa osaksi ulkomaisia. Porkkanasta oli ulkomaisia näytteitä toukoja kesäkuussa. Tutkimukseen sisältyvät lajikkeet olivat seuraavat:

T o m a a till a Virosa, Sonato ja Angela sekä näytteitä, joiden lajike ei ole tiedossa.

S a 1 a a till a pehmeälehtistä keräsalaattia Ostinata, Plevanos, Dandie, Salina, Bellona (kasvihuonelajikkeita), Nya Hilde ja America (avomaalajikkeita) sekä yksi näyte rapealehtistä keräsalaattia, jonka lajike ei ole tiedossa.

P o r k k a n a 11 a pääasiallisesti lajikkeita Nantes 20 Notabene ja Nantes Fancy Notabene; kesäkuulla varhaisporkkanaa Nantes Tip Top kasvihuoneessa kasvatettuna. Ulkomaisten lajikkeiden nimet eivät ole tiedossa.

Täydentävää laatuvertailua varten hankittiin lisäksi torilta joitakin eri hintaisia tomaattinäytteitä. Erillisiä näytteitä hankittiin myös varastointikokeita varten.

Tutkimusmenetelmiksi valittiin eräitä hyvin yksinkertaisia analyysimenetelmiä, joiden avulla oletettiin voitavan helpoimmin arvioida sisäistä laatua. Kaikilla tutkittavilla kasviksilla määritettiin homogenoiduista näytteistä liukoinen kuiva-aine refraktometrisesti (HoRwITz 1975 a). Tomaatilla määritettiin kokonaishappopitoisuus elektrometrisellä titrauksella (HoRwITz 1975 b). Tomaatilla ja salaatilla määritettiin C-vitamiinipitoisuus titraamalla 2,6-diklorfenoli-indofenolilla (FREED 1966). Nitraatti määritettiin salaatista ja porkkanasta käyttäen Orion 93-07 nitraattispesifistä elektrodia (ANon. 1977). Varastointikokeissa mitattiin lisäksi painohäviöt ja varastointitappiot punnitsemalla.

Aistinvaraisessa arvostelussa käytettiin arvopistemenetelmää, jossa asteikkona oli Karlsruhen asteikko 1-9 kaikille ominaisuuksille: ulkonäkö, rakenne, haju ja maku (PAulus ym. 1969). Yhteispisteiden maksimiarvo on näinollen 36. Arvostelijat olivat yleisesti tottuneita aistinvaraiseen arvosteluun, mutta kullakin kasviksella suoritettiin silti ensin harjaannuttamisarvostelu käyttäen näytteitä, jotka ulkonäöltään vastasivat laatuluokkia Ekstra, I, II ja luokittelematon. Aistinvaraiseen arvosteluun liittyen tarkistettiin ulkonäköä arvosteltaessa myös laatuluokka voimassa olevien luokitteluohjeiden mukaan (ANoN. 1970). Arvostelijoilla oli arvostelutilanteessa käytettävissä laatuluokitteluohjeet sekä Karlsruhen asteikko, jossa arvopisteet on myös sanallisesti määritelty ja sidottu laatuluokitukseen (taulukko 1).

Arvostelu suoritettiin kahdessa erässä siten, että ensin arvosteltiin ne ominaisuudet, jotka voitiin todeta kokonaisista kasviksista, ts. laatuluokka, ulkonäkö, rakenne ja haju. Toisessa erässä arvosteltiin makuominaisuudet arvioiden tarpeen mukaan myös rakennetta. Tällöin näytteinä oli sopivia lohkoja saman erän eri näyteyksilöistä. Paitsi pistemäärää arvostelijoiden tuli esittää myös huomautuksia, etenkin jos jotakin virheellisyyttä oli todettavissa. Arvostelussa noudatettiin yleisiä aistinarvostelun järjestelyperiaatteita ja tulosten käsittelyssä laskettiin keskiarvot ja vaihtelurajat (AMERINE ym. 1965). 
Taulukko 1. Kasviksien arvopisteet Karlsruhen asteikon mukaan.

Table 1. Scoring of vegetables according to the Karlsruhe scale.

\begin{tabular}{|c|c|c|c|}
\hline \multirow[b]{2}{*}{$\begin{array}{l}\text { Pistearvo } \\
\text { Score }\end{array}$} & \multicolumn{2}{|c|}{$\begin{array}{l}\text { Maku, haju, rakenne ja ulkonäkö asteikolla } 1-9 \\
\text { Taste, smell, texture and appearance from } 1 \text { to } 9 \text { points }\end{array}$} & $\begin{array}{l}\text { Laatuluokitus } \\
\text { Official classification }\end{array}$ \\
\hline & $\begin{array}{l}\text { Arvosana } \\
\text { Grade }\end{array}$ & $\begin{array}{l}\text { Kuvaus } \\
\text { Detailed description }\end{array}$ & \\
\hline 9 & $\begin{array}{l}\text { erinomainen } \\
\text { excellent }\end{array}$ & $\begin{array}{l}\text { erityisen hyvä, lajille tyypillinen } \\
\text { particularly good, typical of the species }\end{array}$ & $\begin{array}{l}\text { Ekstra } \\
\text { Extra }\end{array}$ \\
\hline 8 & $\begin{array}{l}\text { oikein hyvä } \\
\text { very good }\end{array}$ & $\begin{array}{l}\text { lajille tyypillinen } \\
\text { typical of the species }\end{array}$ & $\begin{array}{l}\text { Ekstra } \\
\text { Extra }\end{array}$ \\
\hline 7 & $\begin{array}{l}\text { hyvä } \\
\text { good }\end{array}$ & $\begin{array}{l}\text { lajille tyypillinen } \\
\text { typical of the species }\end{array}$ & I \\
\hline 6 & $\begin{array}{l}\text { tyydyttävä } \\
\text { satisfactory }\end{array}$ & $\begin{array}{l}\text { normaali, hiukan poikkeava } \\
\text { normal, slightly divergent }\end{array}$ & I \\
\hline 5 & $\begin{array}{l}\text { keskinkertainen } \\
\text { fair }\end{array}$ & $\begin{array}{l}\text { jonkin verran poikkeava } \\
\text { somewhat divergent }\end{array}$ & II \\
\hline 4 & $\begin{array}{l}\text { välttävä } \\
\text { barely acceptable }\end{array}$ & $\begin{array}{l}\text { selvästi poikkeava } \\
\text { clearly divergent }\end{array}$ & II \\
\hline 3 & $\begin{array}{l}\text { puutteellinen } \\
\text { defective }\end{array}$ & $\begin{array}{l}\text { muuttunut } \\
\text { altered }\end{array}$ & $\begin{array}{l}\text { luokittelematon } \\
\text { substandard }\end{array}$ \\
\hline 2 & $\begin{array}{l}\text { huono } \\
\text { poor }\end{array}$ & $\begin{array}{l}\text { muuttunut, virheellinen } \\
\text { altered, unpleasant }\end{array}$ & $\begin{array}{l}\text { luokittelematon } \\
\text { substandard }\end{array}$ \\
\hline 1 & $\begin{array}{l}\text { erittäin huono } \\
\text { very poor }\end{array}$ & $\begin{array}{l}\text { epämiellyttävä } \\
\text { unpalatable }\end{array}$ & $\begin{array}{l}\text { luokittelematon } \\
\text { substandard }\end{array}$ \\
\hline
\end{tabular}

\section{Tulokset}

\section{Salaatti}

a) Tukkukauppanäytteiden tutkimus. Kemiallisten tutkimusten tulokset on koottu taulukkoon 2. Liukoisen kuiva-aineen arvo on ollut alimmillaan marras-helmikuussa, ja nitraattimäärä korkeimmillaan marraskuussa. Standardipoikkeama on suurin $\mathrm{C}$-vitamiinin arvoissa; tämä vitamiini on tunnetusti huonosti säilyvä.

Aistinvaraisen arvostelun tulokset on esitetty piirroksessa 1. Tärkeimmät ominaisuudet ovat maku ja ulkonäkö; viimemainitun pistearvot on esitetty myös erikseen. Pääosa näytteistä on I luokkaan kuuluvaa sekä maun että ulkonäön puolesta. Helmikuussa ja huhtikuussa pistearvot ovat olleet alimmillaan.

Arvot eivät ole olleet riippuvaisia siitä, onko salaatti kotimaista vai ulkomaista.

b) Varastointikokeet. Salaatin varastointikoe suoritettiin kesällä kahdella näyte-erällä (lajike Ostinata). Aluksi varastointi tapahtui kuljetuslaatikoissa 
Taulukko 2. Salaatin laadun kemialliset kriteerit

Table 2. Chemical criteria for quality of lettuce.

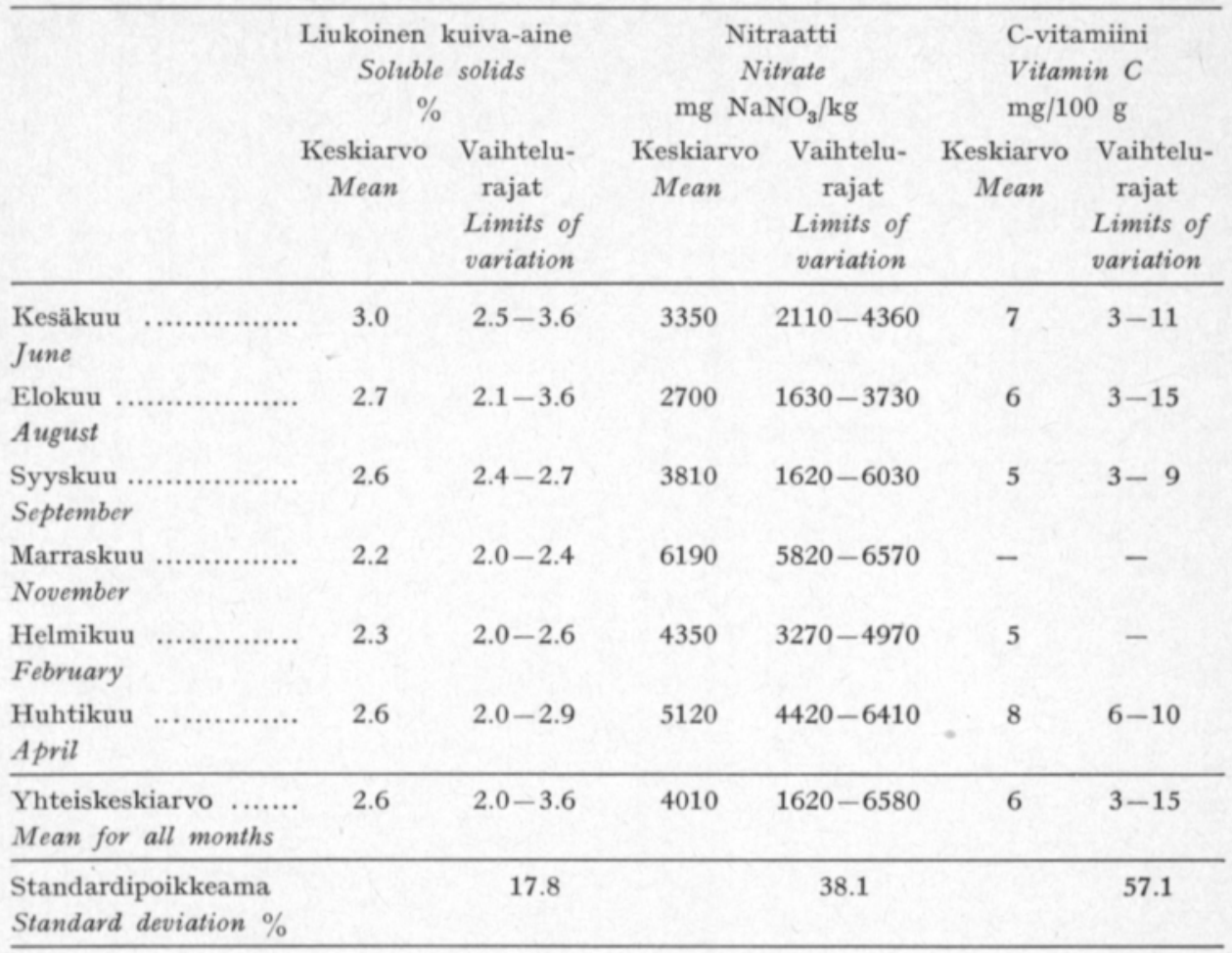
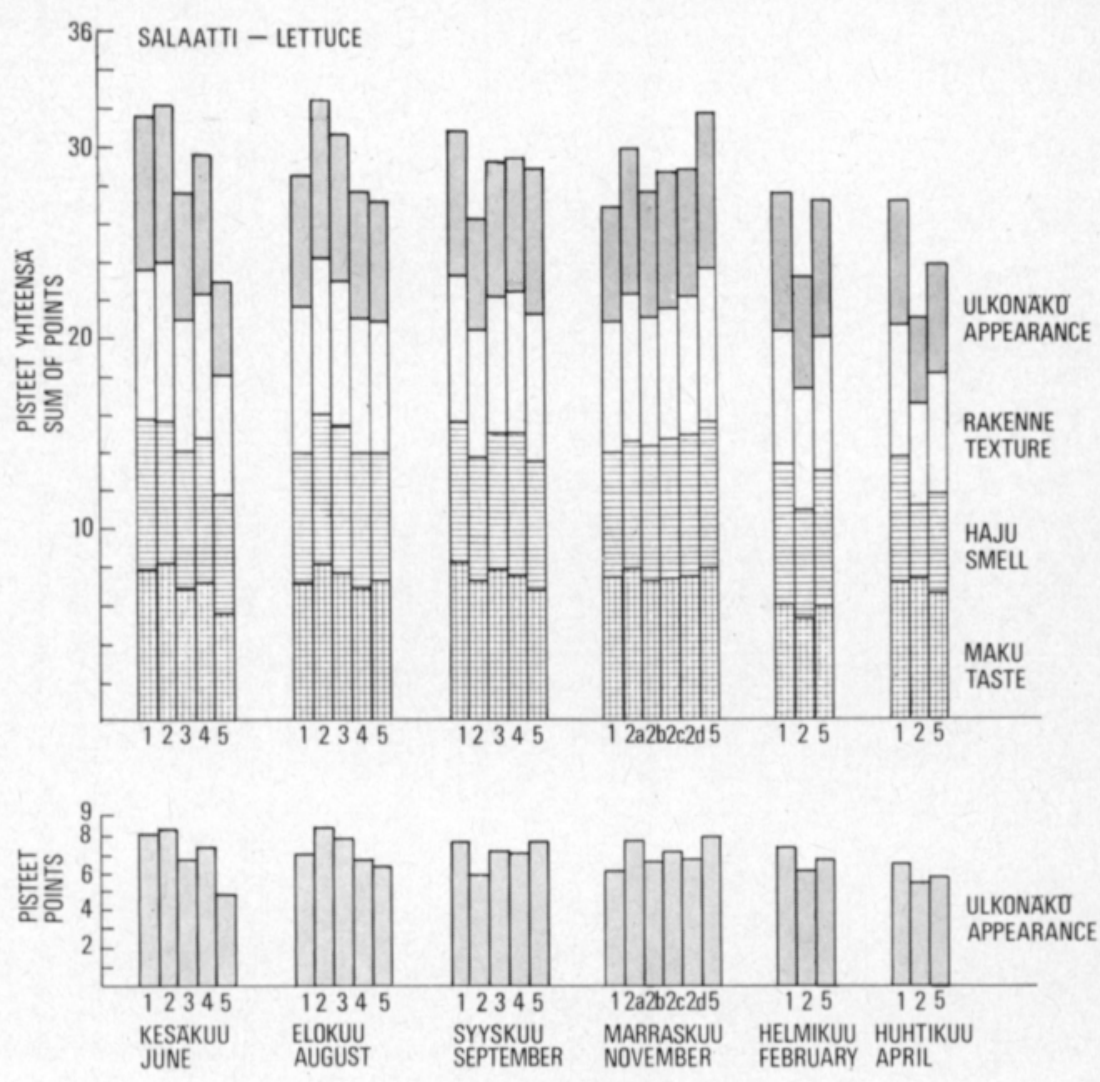

Kuva 1. Salaatin aistinvarainen arvostelu.

Fig. 1. Sensory evaluation of lettuce. 
n. 1 vrk ajan joko kylmävarastossa $\left(4.5-5.5^{\circ} \mathrm{C}\right.$, suhteellinen kosteus $\left.43-50 \%\right)$ tai huoneenlämmössä $\left(20.5-23^{\circ} \mathrm{C}\right.$, kosteus $\left.70-95 \%\right)$. Tämän jälkeen ne pakattiin muovipusseihin ja varastoitiin edelleen n. 4 vrk joko viileässä $\left(+10^{\circ} \mathrm{C}\right.$, kosteus $50 \%$ ) tai huoneenlämmössä $\left(21.5-23.5^{\circ} \mathrm{C}\right.$, kosteus $\left.37-55 \%\right)$. Varastoinnille lasketut lämpösummat, ts. kaikkien vuorokausien asteet $0^{\circ} \mathrm{C}: \mathrm{n}$ yläpuolella yhteenlaskettuina, on esitetty taulukossa 3 .

Taulukko 3. Salaatin varastoinnissa eri näytteille lasketut lämpösummat.

Table 3. Temperature totals of the different samples in the storage of lettuce.

\begin{tabular}{|c|c|c|c|}
\hline $\begin{array}{l}\text { Näytteen koodi } \\
\text { Code of Sample }\end{array}$ & $\begin{array}{ll}1 & \text { vrk } \\
1 & \text { day }\end{array}$ & $\begin{array}{l}4 \text { vrk } \\
4 \text { days }\end{array}$ & $\begin{array}{c}\text { Lämpösumma } \\
\text { Temperature totals }\end{array}$ \\
\hline $\mathrm{K} 1, \mathrm{~L} 1 \ldots \ldots \ldots \ldots$ & $4^{\circ} \mathrm{C}$ & $10^{\circ} \mathrm{C}$ & 44 \\
\hline K 2, L $2 \ldots \ldots \ldots \ldots$ & $4^{\circ} \mathrm{C}$ & $22^{\circ} \mathrm{C}$ & 92 \\
\hline K 3 , L 3 ,........... & $22^{\circ} \mathrm{C}$ & $10^{\circ} \mathrm{C}$ & 62 \\
\hline K 4, L $4 \ldots \ldots \ldots \ldots$. & $22^{\circ} \mathrm{C}$ & $22^{\circ} \mathrm{C}$ & 110 \\
\hline
\end{tabular}

Näytteistä mitattiin nestehukka yhden vuorokauden kuljetuslaatikkovarastoinnin jälkeen. Arvot olivat seuraavat:

$$
\begin{array}{lrll}
\text { Kylmävarastointi (n. }+5^{\circ} \mathrm{C} \text { ) } & \ldots \ldots \ldots \ldots \ldots & 0.9 \% \\
\text { Huoneenlämpö } & \text { (n. } \left.+22^{\circ} \mathrm{C}\right) & \ldots \ldots \ldots \ldots . . & 5.4 \%
\end{array}
$$

Jatkovarastoinnin jälkeen mitattiin painohäviöiden lisäksi kauppakunnostustappiot. Tulokset on esitetty taulukossa 4 .

Taulukko 4. Salaatin varastoinnissa tapahtuvat painohäviöt ja kauppakunnostustappiot.

\begin{tabular}{|c|c|c|c|c|c|}
\hline \multirow[t]{2}{*}{$\begin{array}{l}\text { Numero } \\
\text { Number }\end{array}$} & \multirow[t]{2}{*}{$\begin{array}{c}\text { Lämpösumma } \\
\text { Temperature } \\
\text { totals }\end{array}$} & \multicolumn{2}{|c|}{$\begin{array}{c}\text { Painohäviö } \\
\text { Weight loss } \\
\% \\
\text { Sarja - Series }\end{array}$} & \multicolumn{2}{|c|}{$\begin{array}{c}\text { Kauppakunnostustappio } \\
\text { Trimming loss } \\
\% \\
\text { Sarja }- \text { Series }\end{array}$} \\
\hline & & K & L & K & L \\
\hline 1 & 44 & 0.5 & & 13 & \\
\hline 1 & 44 & & 0.5 & & 22 \\
\hline 3 & 62 & 0.8 & & 15 & \\
\hline 3 & 62 & & 0.4 & & 25 \\
\hline 2 & 92 & 1.1 & & 25 & \\
\hline 2 & 92 & & 0.8 & & 47 \\
\hline 4 & 110 & 0.8 & & 25 & \\
\hline 4 & 110 & & 0.9 & & 32 \\
\hline
\end{tabular}
Table 4. Weight losses and trimming losses during storage of lettuce. 
Varastointi pakattuna on suuresti vähentänyt painohäviötä. Korkeamman lämpötilan vaikutus onkin tullut selvimmin näkyviin kauppakunnostustappion suurenemisena.

Varastoinnin vaikutus liukoisen kuiva-aineen ja C-vitamiinin määrään on esitetty taulukossa 5 .

Taulukko 5. Salaatin varastoinnissa tapahtuvat muutokset liukoisessa kuiva-aineessa ja C-vitamiinissa.

Table 5. Changes in soluble solids and vitamin C during storage of lettuce

\begin{tabular}{|c|c|c|c|c|c|}
\hline \multirow[t]{2}{*}{$\begin{array}{l}\text { Numero } \\
\text { Number }\end{array}$} & \multirow[t]{2}{*}{$\begin{array}{c}\text { Lämpösumma } \\
\text { Temperature } \\
\text { totals }\end{array}$} & \multicolumn{2}{|c|}{$\begin{array}{l}\text { Liukoisen kuiva-aineen muutos, } \\
\text { alkuarvosta } \\
\text { Change in soluble solids from } \\
\text { initial value } \\
\% \\
\text { Sarja }- \text { Series }\end{array}$} & \multicolumn{2}{|c|}{$\begin{array}{c}\text { C-vitamiinin häviō, alkuarvosta } \\
\text { Loss of vitamin C } \\
\% \\
\text { Sarja }- \text { Series }\end{array}$} \\
\hline & & $\mathrm{K}$ & $\mathrm{L}$ & $\mathrm{K}$ & L \\
\hline 1 & 44 & -3.5 & & 44 & \\
\hline 1 & 44 & & -8.3 & & 46 \\
\hline 3 & 62 & 0 & & 60 & \\
\hline 3 & 62 & & -4.2 & & 49 \\
\hline 2 & 92 & -10.3 & & 73 & \\
\hline 2 & 92 & & +8.3 & & 87 \\
\hline 4 & 110 & +3.5 & & 60 & \\
\hline 4 & 110 & & 0 & & 87 \\
\hline
\end{tabular}

Liukoisen kuiva-aineen muutokset ovat olleet korkeintaan tasoa $0,3 \mathrm{~g} /$ 100 g. Muutos on pääasiassa ollut alenemista, mutta eräissä tapauksissa on tapahtunut kohoamistakin. C-vitamiinin arvot sen sijaan ovat alentuneet sitä enemmän mitä korkeampi varastoinnin lämpötila.

Aistinvaraisen arvostelun tulokset on koottu taulukkoon 6. Salaatin laatu on varastoitaessa suuresti huonontunut, mikä tulee esille selvimmin ulkonäköpisteissä. Mitä korkeampi lämpösumma, sitä suurempi pistearvojen aleneminen. 
Taulukko 6. Salaatin varastoinnissa tapahtuvat muutokset aistinvaraisesti todettavissa ominaisuuksissa.

Table 6. Changes in sensory properties during storage of lettuce.

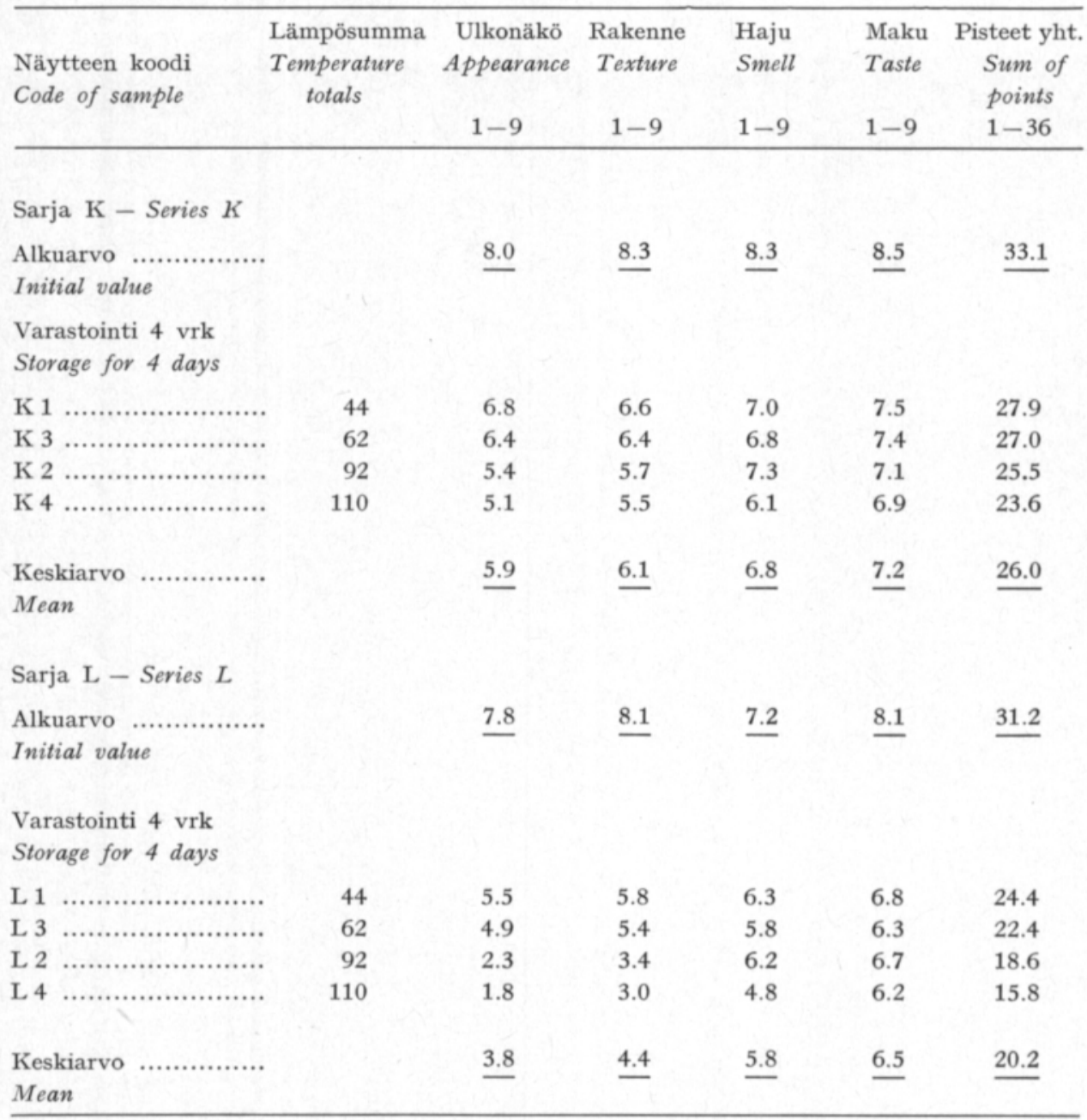

\section{Tomaatti}

a) Tukkukauppanäytteiden tutkimus. Kemiallisten tutkimusten tulokset on koottu taulukkoon 7 .

Liukoisen kuiva-aineen arvot ovat olleet korkeimmat helmi-huhtikuussa, mikä johtuu ulkomaisten näytteiden korkeista arvoista. On syytä mainita, että tässä tutkimussarjassa korkea liukoisen kuiva-aineen arvo ei ole samalla merkinnyt korkeaa aistinvaraista laatua: huhtikuussa oli aistinvaraisilta ominaisuuksiltaan paras näyte kotimainen (liukoinen kuiva-aine $4.5 \%$ ) ja huonoin ulkomainen (liukoinen kuiva-aine $7.6 \%$ ).

Myös happopitoisuuden arvot ovat olleet korkeimmat helmi-huhtikuussa, mikä samoin johtuu ulkomaisista näytteistä. C-vitamiinin arvojen vaihtelu taas ei ole riippunut tomaattien alkuperästä eikä vuodenajasta.

Aistinvaraisen arvostelun tulokset käyvät ilmi piirroksesta 2 . 
Taulukko 7. Tomaatin laadun kemialliset kriteerit.

Table 7. Chemical criteria for quality of tomato.

\begin{tabular}{|c|c|c|c|c|c|c|}
\hline & \multicolumn{2}{|c|}{$\begin{array}{c}\text { Liukoinen kuiva-aine } \\
\text { Soluble solids } \\
\%\end{array}$} & \multicolumn{2}{|c|}{$\begin{array}{c}\text { Happopitoisuus } \\
\text { Acid content } \\
\mathrm{ml} 0.1 \quad \mathrm{M} \mathrm{NaOH} / 1\end{array}$} & \multicolumn{2}{|c|}{$\begin{array}{l}\text { C-vitamiini } \\
\text { Vitamin C } \\
\mathrm{mg} / 100 \mathrm{~g}\end{array}$} \\
\hline & $\begin{array}{l}\text { Keskiarvo } \\
\text { Mean }\end{array}$ & $\begin{array}{l}\text { Vaihtelu- } \\
\text { rajat } \\
\text { Limits of } \\
\text { variation }\end{array}$ & $\begin{array}{c}\text { Keskiarvo } \\
\text { Mean }\end{array}$ & $\begin{array}{l}\text { Vaihtelurajat } \\
\begin{array}{l}\text { Limits of } \\
\text { variation }\end{array}\end{array}$ & $\begin{array}{l}\text { Keskiarvo } \\
\text { Mean }\end{array}$ & $\begin{array}{l}\text { Vaihtelu- } \\
\text { rajat } \\
\text { Limits of } \\
\text { variation }\end{array}$ \\
\hline $\begin{array}{l}\text { Kesäkuu } \\
\text { June }\end{array}$ & 4.5 & $4.1-4.9$ & 78.2 & $67.2-86.6$ & 16 & $11-23$ \\
\hline $\begin{array}{l}\text { Elokuu } \\
\text { August }\end{array}$ & 4.5 & $4.3-4.7$ & 67.5 & $50.0-79.4$ & 19 & $15-21$ \\
\hline $\begin{array}{l}\text { Syyskuu ........................ } \\
\text { September }\end{array}$ & 4.4 & $4.2-4.5$ & 72.3 & $62.5-84.7$ & 15 & $13-17$ \\
\hline $\begin{array}{l}\text { Marraskuu .................. } \\
\text { November }\end{array}$ & 4.8 & $4.6-5.0$ & 78.4 & $74.2-82.6$ & 17 & $15-18$ \\
\hline $\begin{array}{l}\text { Helmikuu } \\
\text { February }\end{array}$ & 5.7 & $5.4-6.0$ & 88.2 & $76.4-103.5$ & 18 & $15-21$ \\
\hline $\begin{array}{l}\text { Huhtikuu } \\
\text { April }\end{array}$ & 5.2 & $4.2-7.6$ & 88.1 & $79.5-100.5$ & 16 & $12-23$ \\
\hline $\begin{array}{l}\text { Yhteiskeskiarvo ........ } \\
\text { Mean for all months }\end{array}$ & 4.7 & $4.1-7.6$ & 76.7 & $50.0-103.5$ & 17 & $11-23$ \\
\hline $\begin{array}{l}\text { Standardipoikkeama } \\
\text { Standard deviation \% }\end{array}$ & & 13.4 & & 14.4 & & 17.9 \\
\hline
\end{tabular}

Tutkitut näytteet ovat makunsa puolesta olleet miltei kaikki I luokan tasoa, mutta ulkonäön puolesta muutamat näytteet ovat olleet heikompia. Huomautusten perusteella tiedetään tämän johtuneen pääasiassa pintavioista ja pehmenemisestä. Joissakin tapauksissa taas tomaatit olivat arvosteltaessa vielä liian raakoja. Viimemainittu seikka saattaa korjaantua tomaatteja varastoitaessa, mutta pehmenneet ja pintavikaiset tomaatit sen sijaan huononevat vielä varastoitaessa.

b) Torilta ostettujen eri hintaisten tomaattien vertailu. Tämä tutkimus suoritettiin edellä selostetun sarjan täydennykseksi. Näytteet hankittiin syyskuussa, jolloin tarjonta on runsaimmilleen. Kilohinnat olivat $8 \mathrm{mk}, 6 \mathrm{mk}$ ja $4 \mathrm{mk}$.

Kemiallisten analyysien tulokset on esitetty taulukossa 8, aistinvaraisen arvostelun tulokset taulukossa 9 .

Hintatasolla ei ole ollut merkittävää vaikutusta analyysiarvoihin, ei edes C-vitamiinin määrään. Sen sijaan aistinvaraisessa arvostelussa hintaluokan vaikutus on tullut selvästi esille lähinnä ulkonäössä ja rakenteessa. Maussa erot ovat olleet melko pieniä. Halvoilla tomaateilla on tärkein hintaan vaikuttava tekijä ilmeisesti ollut jäljellä oleva säilyvyysaika. Jos laatuvaatimuksia noudatettaisiin tiukasti, ei kaupan pidetyissä tomaateissa tulisi sallia avohalkeamia. Tomaateissa ei kuitenkaan vielä esiintynyt hometta, ja arvostelijat pitivät halpojakin tomaatteja virheistä huolimatta kauppakelpoisina, joskin heikkolaatuisina. 

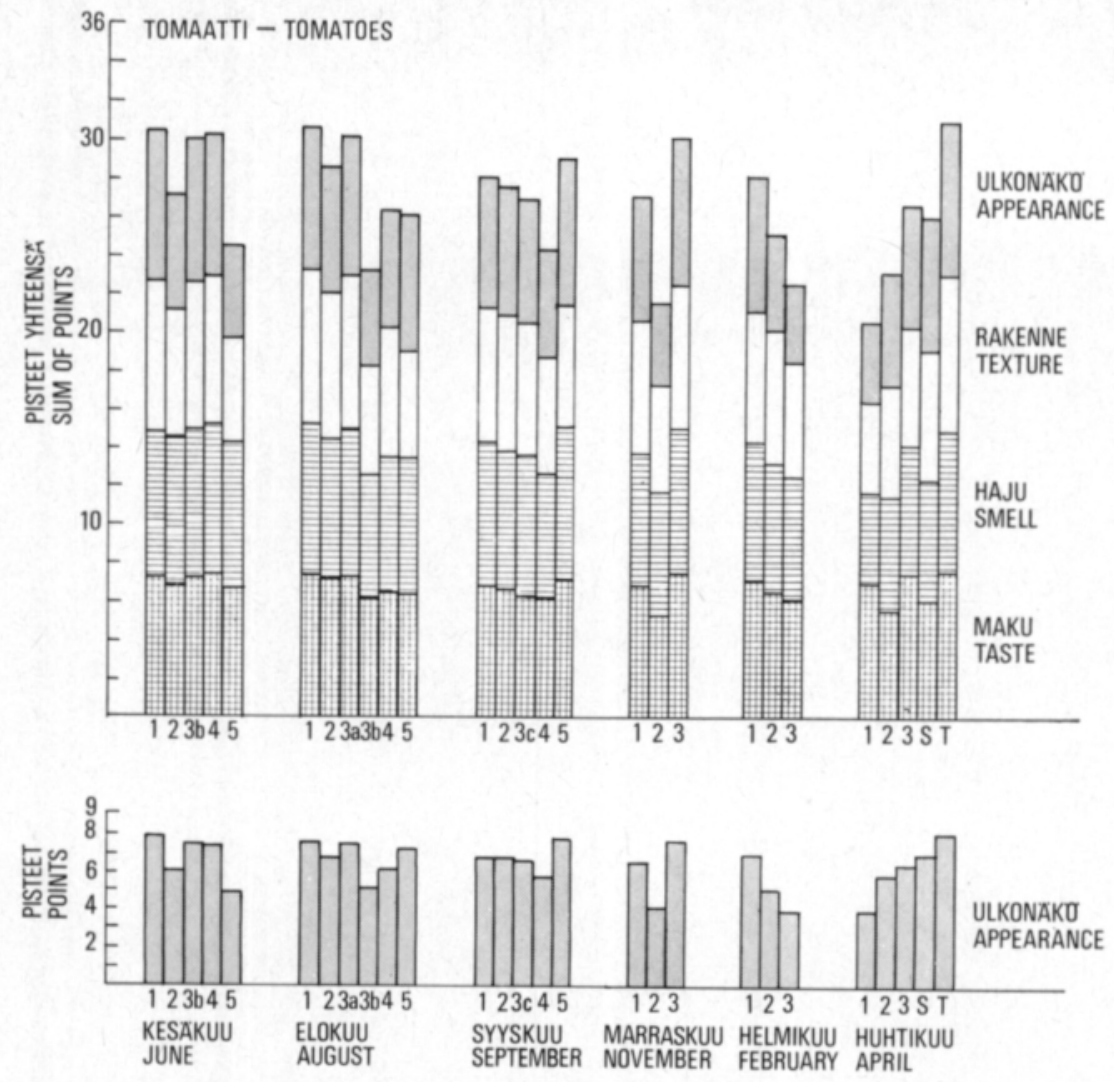

Kuva 2. Tomaatin aistinvarainen arvostelu.

Fig. 2. Sensory evaluation of tomatoes.

Taulukko 8. Torilta ostettujen tomaattien laadun kemialliset kriteerit.

Table 8. Chemical criteria for quality of tomatoes bought in the market.

\begin{tabular}{|c|c|c|c|}
\hline $\begin{array}{l}\text { Hintaluokka } \\
\text { Price class }\end{array}$ & $\begin{array}{c}\text { Liukoinen kuiva-aine } \\
\text { Soluble solids } \\
\%\end{array}$ & $\begin{array}{c}\text { Happopitoisuus } \\
\text { Acid content } \\
\mathrm{ml} 0.1 \mathrm{M} \mathrm{NaOH} / 100 \mathrm{~g}\end{array}$ & $\begin{array}{l}\text { C-vitamini } \\
\text { Vitamin } C \\
\mathrm{mg} / 100 \mathrm{~g}\end{array}$ \\
\hline $8 \mathrm{mk} / \mathrm{kg} \quad \ldots \ldots \ldots$ & 4.3 & 57.9 & 18 \\
\hline $6 \mathrm{mk} / \mathrm{kg} \ldots \ldots \ldots$ & 4.7 & 63.7 & 19 \\
\hline $4 \mathrm{mk} / \mathrm{kg} \quad \ldots . . . .$. & 4.3 & 61.1 & 20 \\
\hline
\end{tabular}

Taulukko 9. Torilta ostettujen tomaattien laatu aistinvaraisesti arvosteltuna.

Table 5. Sensory quality of tomatoes bought in the market.

\begin{tabular}{|c|c|c|c|c|c|}
\hline $\begin{array}{l}\text { Hintaluokka } \\
\text { Price class }\end{array}$ & $\begin{array}{c}\text { Ulkonãkö } \\
\text { Appearance } \\
1-9\end{array}$ & $\begin{array}{c}\text { Rakenne } \\
\text { Texture } \\
1-9\end{array}$ & $\begin{array}{c}\text { Haju } \\
\text { Smell } \\
1-9\end{array}$ & $\begin{array}{c}\text { Maku } \\
\text { Taste } \\
1-9\end{array}$ & $\begin{array}{c}\text { Pisteitä yhteensä } \\
\text { Sum of points } \\
1-36\end{array}$ \\
\hline $8 \mathrm{mk} / \mathrm{kg} \ldots \ldots \ldots \ldots \ldots$ & 7.1 & 7.4 & 7.6 & 7.5 & 29.6 \\
\hline $6 \mathrm{mk} / \mathrm{kg} \quad \ldots \ldots \ldots \ldots \ldots$ & 5.4 & 6.9 & 7.3 & 71 & 26.7 \\
\hline $4 \mathrm{mk} / \mathrm{kg} \quad \ldots \ldots \ldots \ldots \ldots \ldots$ & 4.5 & 5.6 & 7.3 & 6.7 & 24.1 \\
\hline
\end{tabular}


c) Varastointikokeet. Tomaatin kesällä suoritetuissa varastointikokeissa oli kaksi näyte-erää (lajike Virosa). Näytteitä varastoitiin ensin kuljetuslaatikoissaan n. 1 vrk, kummastakin erästä puolet viileässä $\left(+10^{\circ} \mathrm{C}\right.$, suhteellinen kosteus n. $50 \%$ ) ja puolet huoneenlämmössä $\left(+18-22.5^{\circ} \mathrm{C}\right.$, kosteus $41-57 \%$ ). Sen jälkeen ne pakattiin kuluttajapakkauksiin (4 tomaatin erä styroksalustalle, peitteenä kelmu) ja varastoitiin edelleen viileässä tai huoneenlämmössä 9 vrk (L-sarja) tai 13 vrk (R-sarja). Laatututkimukset suoritettiin alussa, 2 vrk varastoinnin jälkeen sekä lopussa. Varastointikaavio ja lasketut lämpösummat on esitetty taulukossa 10 .

Näytteistä mitattiin painohäviöt punnitsemalla. Piirros 3 esittää hävikin ja varastoinnin lämpösummien korrelaatiota. Lämpösummien kohotessa on häviö suurentunut.

Liukoisen kuiva-aineen, happomäärän ja C-vitamiinin määrän muutokset varastoinnin kuluessa on esitetty piirroksissa 4,5 ja 6 . Liukoinen kuiva-aine on yleensä aluksi vähän kohonnut ja sen jälkeen alentunut. Ero on kuitenkin ollut

Taulukko 10. Tomaatin varastoinnissa eri näytteille lasketut lämpösummat.

Table 10. Temperature totals of the different samples in the storage of tomatoes.

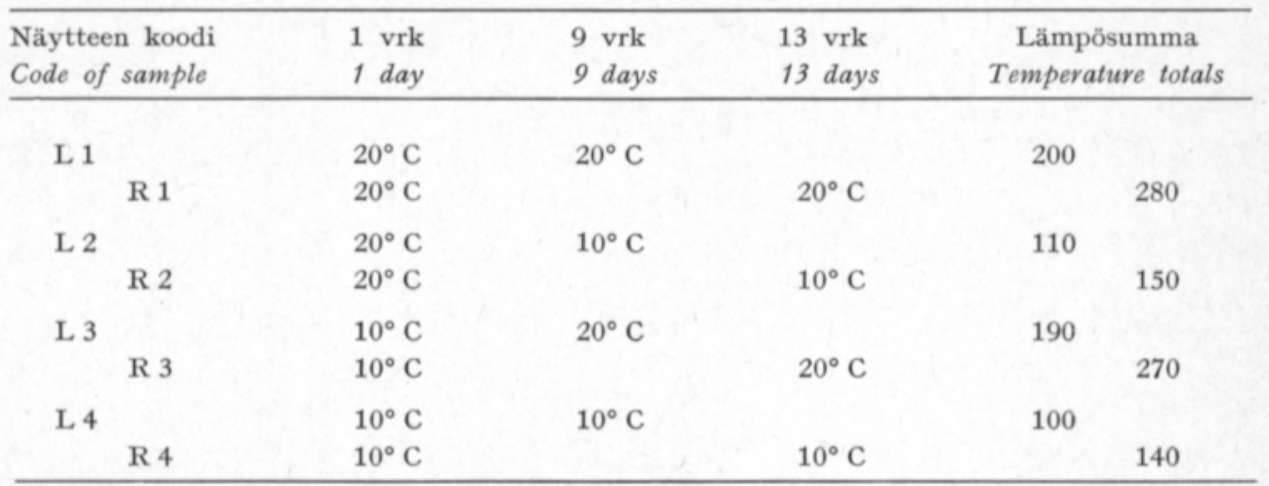

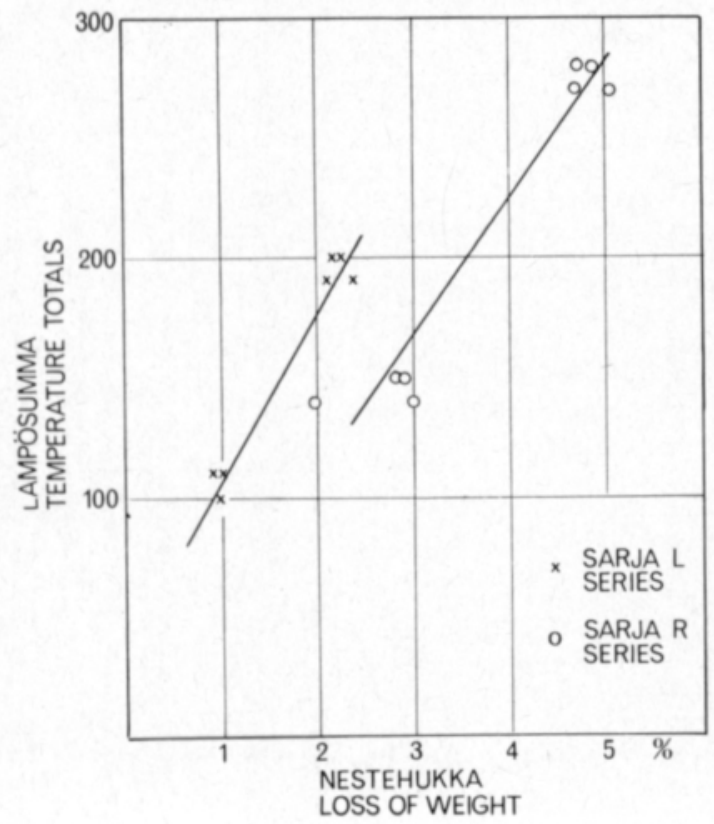

Kuva 3. Korrelaatio painohäviöiden ja varastoinnin lämpösummien välillä tomaattia varastoitaessa.

Fig. 3. Correlation between the weight loss of tomatoes and the temperature totals during storage. 

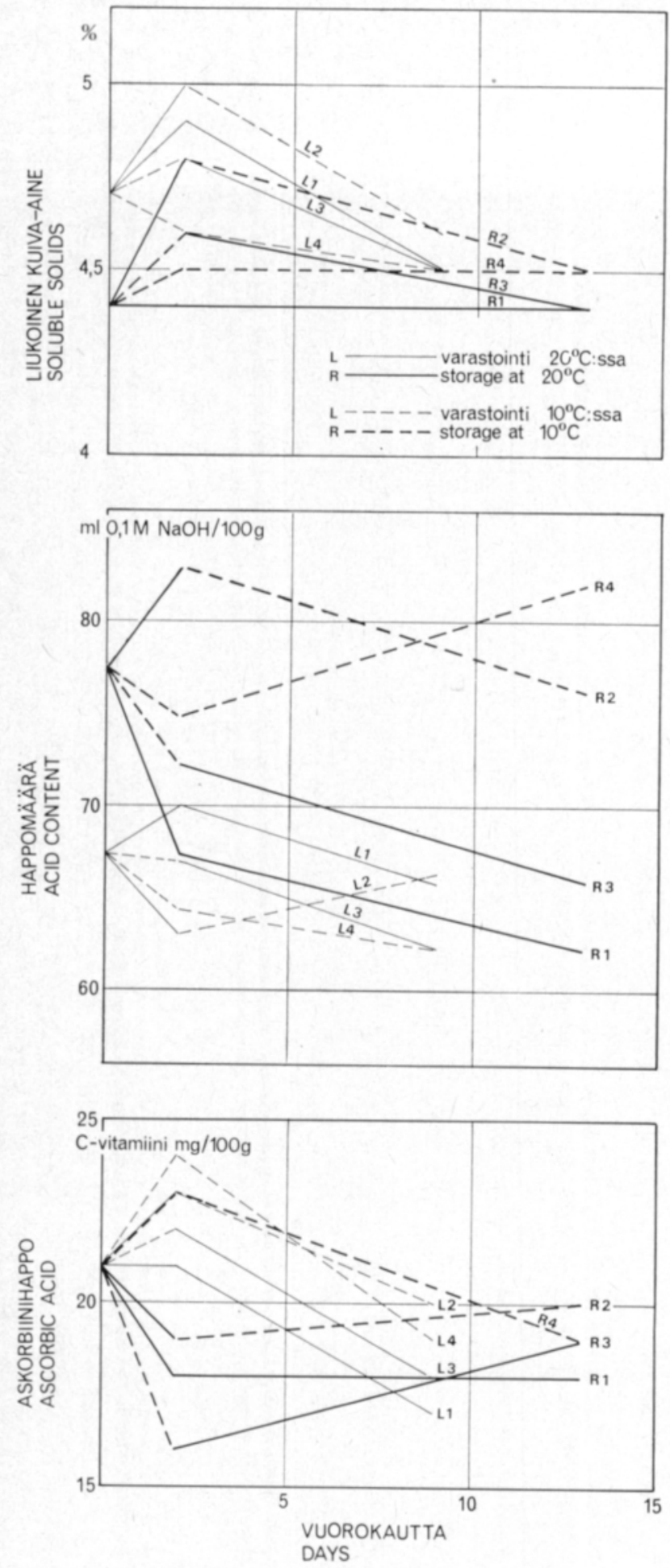

Kuva 4. Muutokset tomaatin liukoisessa kuiva-aineessa varastoinnin aikana.

Fig. 4. Changes in soluble solids of tomatoes during storage.

Kuva 5. Muutokset tomaatin happopitoisuudessa varastoinnin aikana.

Fig. 5. Changes in acid content of tomatoes during storage.

Kuva 6. Muutokset tomaatin askorbiinihappopitoisuudessa varastoinnin aikana.

Fig. 6. Changes in ascorbic acid of tomatoes during storage. 
Taulukko 11. Tomaatin varastoinnissa tapahtuvat muutokset aistinvaraisesti todettavissa ominaisuuksissa.

Table 11. Changes in sensory properties during storage of tomatoes.

\begin{tabular}{lcccccc}
\hline $\begin{array}{l}\text { Näytteen koodi } \\
\text { Code of sample }\end{array}$ & $\begin{array}{c}\text { Lämpösumma } \\
\text { Temperature } \\
\text { totals }\end{array}$ & $\begin{array}{c}\text { Appearance } \\
\text { Aplkökö }\end{array}$ & $\begin{array}{r}\text { Rakenne } \\
\text { Texture }\end{array}$ & $\begin{array}{r}\text { Haju } \\
\text { Smell }\end{array}$ & $\begin{array}{r}\text { Maku } \\
\text { Taste }\end{array}$ & $\begin{array}{c}\text { Pisteet } \\
\text { yhteensä } \\
\text { Sum of points }\end{array}$ \\
\hline
\end{tabular}

Sarja L

Series $L$

Alkuarvo

Initial value

$\begin{array}{lllll}7.5 & \underline{7.8} & \underline{7.9} & \underline{7.4} & \underline{30.6}\end{array}$

Varastointi 2 vrk

Storage for 2 days

\begin{tabular}{|c|c|c|c|c|c|}
\hline L 3 ....................... & 20 & 7.6 & 7.3 & 8.1 & 7.9 \\
\hline $\mathrm{L} 4 \ldots \ldots \ldots \ldots \ldots \ldots \ldots \ldots \ldots \ldots \ldots \ldots$ & 20 & 7.5 & 7.4 & 7.9 & 7.7 \\
\hline L 1 ...................... & 40 & 8.8 & 8.0 & 8.4 & 7.3 \\
\hline 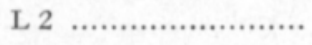 & 40 & 8.4 & 7.7 & 8.1 & 7.7 \\
\hline 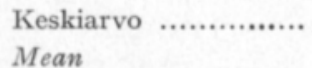 & & 8.1 & 7.6 & 8.1 & 7.7 \\
\hline
\end{tabular}

Varastointi 9 vrk

Storage for 9 days

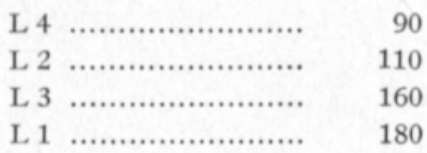

7.9

$8.2 \quad 7.7$

7.7

7.6

7.5

30.6

8.2

7.8

7.7

31.4

Keskiarvo

8.0

Mean

$\underline{7.4}$

$\underline{7.5}$

30.3

Sarja R

Series $R$

Alkuarvo

Initial value

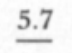

6.4

6.2

23.3

Varastointi 2 vrk

Storage for 2 days

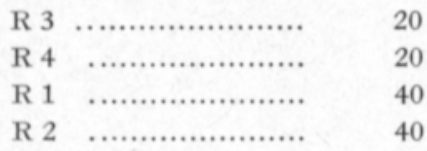

6.3

6.1

6.8

7.3

7.2

27.6

20

6.1
6.8

6.6

6.8

Keskiarvo

\section{Mean}

Varastointi 13 vrk

Storage for 13 days

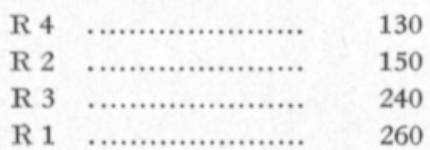

Keskiarvo 260 
enintään $5 \%$. Hapon määrä on pääsääntöisesti alentunut varastoitaessa ja pysynyt korkeana vain silloin kun on pitkään varastoitu viileässä, poikkeama alkuarvosta on ollut enintään $10 \%$. C-vitamiinin arvot ovat pääsääntöisesti alentuneet, kuitenkin enintään $20 \%$.

Aistinvaraisen arvostelun tulokset on esitetty taulukossa 11. L-sarjassa ovat arvot pysyneet jokseenkin samalla tasolla koko 9 vrk varastoinnin ajan. R-sarjassa näytteet olivat alussa raaempia, ja aistinvaraisesti todettava laatu on parantunut varastoitaessa 13 vrk. Varastoinnin lämpösummilla ei ole ollut selvää vaikutusta pistearvoihin. Varastoinnin lopussa laatutaso on ollut korkea.

\section{Porkkana}

Tukkukauppanäytteiden tutkimus. Kemiallisten analyysien tulokset on koottu taulukkoon 12. Liukoisen kuiva-aineen korkeimmat arvot johtuvat siitä, että näytesarjassa on ollut mukana ulkomaista porkkanaa. Varhaisporkkanalla taas arvo on ollut alhainen. Nitraattimäärässä vaihtelu on ollut suuri, korkein arvo oli varhaisporkkanalla (1 $500 \mathrm{mg} / \mathrm{kg}$ ). Kotimaisen ja ulkomaisen porkkanan nitraattipitoisuus oli samaa tasoa.

Aistinvaraisen arvostelun mukaan (piirros 7) vastasivat näytteiden ulkonäköominaisuudet I luokkaa, vaikka jokin arvo olikin alarajalla. Makuvirheenä todettiin yhdessä näytteessä kitkeryyttä ja kellarinmakua, mistä aiheutui alhainen pistemäärä. Eräissä muissakin näytteissä on ollut huomautuksia vähäisestä kitkeryydestä.

Taulukko 12. Porkkanan laadun kemialliset kriteerit.

Chemical criteria for quality of carrots.

\begin{tabular}{|c|c|c|c|c|}
\hline & $\begin{array}{r}\text { Liukoi } \\
\text { So } \\
\text { Keskiarvo } \\
\text { Mean }\end{array}$ & $\begin{array}{l}\text { kuiva-aine } \\
\text { ble solids } \\
\text { Vaihtelurajat } \\
\text { Limits of variation }\end{array}$ & $\begin{array}{c}\text { Nitraatti } \\
\text { Nitrate } \\
\mathrm{mg} \mathrm{NaNO}_{3} / \mathrm{kg} \\
\text { Keskiarvo } \\
\text { Mean }\end{array}$ & $\begin{array}{c}\text { Vaihtelurajat } \\
\text { Limits of variation }\end{array}$ \\
\hline $\begin{array}{l}\text { Kesäkuu } \\
\text { June }\end{array}$ & 9.6 & $8.4-10.0$ & 610 & $260-1500$ \\
\hline 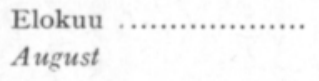 & 7.8 & $7.3-8.1$ & 350 & $130-630$ \\
\hline $\begin{array}{l}\text { Syyskuu } . . . \ldots \ldots \ldots \ldots \ldots \\
\text { September }\end{array}$ & 8.3 & $7.5-9.2$ & 450 & $240-1000$ \\
\hline $\begin{array}{l}\text { Marraskuu } \\
\text { November }\end{array}$ & 8.8 & $8.5-8.9$ & 530 & $420-670$ \\
\hline $\begin{array}{l}\text { Helmikuu } \\
\text { February }\end{array}$ & 9.2 & $8.9-9.6$ & 450 & $290-470$ \\
\hline $\begin{array}{l}\text { Toukokuu } . . . \cdots \cdots \cdots \cdots \\
\text { May }\end{array}$ & 8.9 & $7.7-10.2$ & 460 & $140-980$ \\
\hline $\begin{array}{l}\text { Yhteiskeskiarvo ........ } \\
\text { Mean for all months }\end{array}$ & 8.6 & $7.3-10.2$ & 450 & $130-1500$ \\
\hline $\begin{array}{l}\text { Standardipoikkeama } \\
\text { Standard deviatıon } \%\end{array}$ & & 10.4 & & 65.5 \\
\hline
\end{tabular}



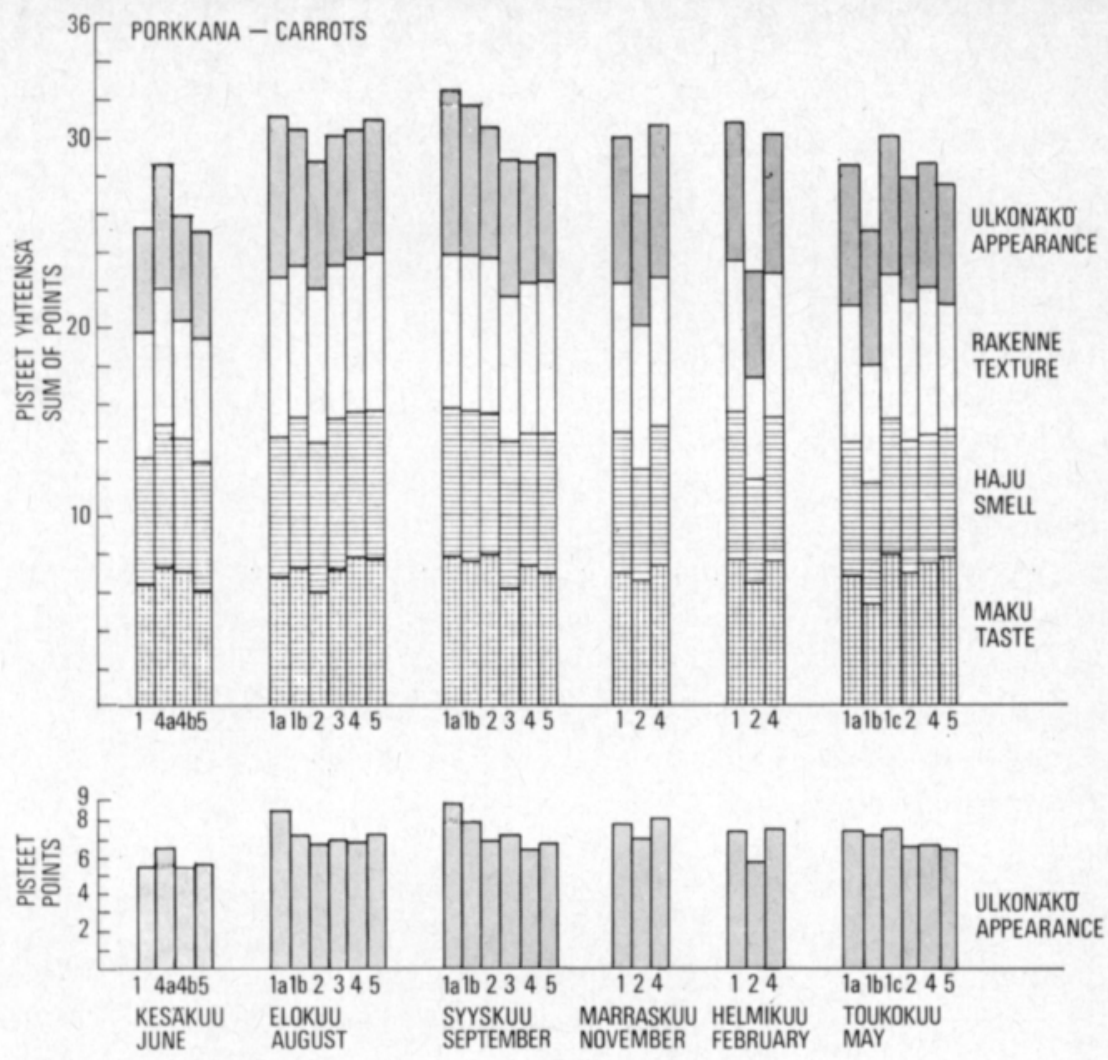

Kuva 7. Porkkanan aistinvarainen arvostelu.

Fig. 7. Sensory evaluation of carrots.

\section{Tulosten tarkastelu}

Sisäistä laatua karakterisoitaessa on tässä tutkimuksessa käytetty analyysi menetelminä liukoisen kuiva-aineen, happopitoisuuden, C-vitamiinin ja nitraatin määrittämistä sekä varastointikokeissa myös painohäviön ja kauppakunnostustappion mittaamista. Liukoisen kuiva-aineen määrittäminen on nopea, mutta jonkin verran epätarkka menetelmä. Tavanomaisesti liukoinen kuivaaine kohoaa kypsyessä ja alenee korjuun jälkeisessä varastoinnissa. Korkea liukoisen kuiva-aineen määrä ei kuitenkaan aina merkitse hyvää aistinvaraista laatua, kuten esim. tomaatin tutkimukset osoittivat. Tähän vaikuttaa markkinoilla olevien kasviksien heterogeenisyys mm. alkuperän, lajikkeen, varastointiajan yms. tekijöiden vaikutuksesta. Tästä johtuen voi aiheutua vaikeuksia käytettäessä liukoista kuiva-ainetta laatukriteerinä.

Tomaatilla tutkittu happopitoisuus on riippuvainen mm. lajikkeesta ja kypsyysasteesta. Tämän ominaisuuden korrelaatio laatuun ei ole kovin selväpiirteinen.

C-vitamiinin määrään vaikuttavat monet seikat, kuten lajike, kypsyysaste, sääsuhteet, varastointi jne. Se on kylläkin laadun kriteeri, mutta sen käyttö voi osoittautua vaikeaksi. Pitoisuus muuttuu helposti, ja muutokset ovat eri tapauksissa hyvin erisuuruiset. Esim. salaatin varastoinnissa aleneminen 
oli hyvin huomattava ja samansuuntainen aistinvaraisten ominaisuuksien huononemisen kanssa. Eri hintaisilla tomaateilla taas ei C-vitamiinin määrässä ollut eroja, mutta aistinvaraiset ominaisuudet muuttuivat hintatason mukaisesti.

Nitraatin määrissä esiintyi sekä salaatilla että porkkanalla suuria vaihteluita. Tähän laatutekijään on viime aikoina alettu kiinnittää erityistä huomiota mm. lastenruokien valmistuksessa esiintyvän riskin vuoksi. Nitraatin määrään vaikuttavat monet tekijät, etenkin ko. kasvin taipumus nitraatin keräämiseen, lannoitus sekä sääsuhteet. Tämä ominaisuus ei ole korrelaatiossa ulkoisen laatuluokituksen eikä aistinvaraisten ominaisuuksien kanssa, vaan on erillinen. Nitraattikysymyksiä olisi aiheellista tutkia laajemmin niiden tärkeyden vuoksi.

Nestehukka liittyy kuihtumiseen ja on laadun kriteeri. Tällöin jo ulkoinenkin laatu alenee selvästi. Pakatulla salaatilla oli kauppakunnostustappio varastoitaessa paljon suurempi kuin nestehukka.

Paitsi kemiallisin analyysein on näytteiden sisäistä laatua tutkittu myös aistinvaraisen arvostelun avulla. Tällä menetelmällä on saatu johdonmukaisia ja luotettavia tuloksia mausta, hajusta, rakenteesta ja ulkonäöstä, minkä lisäksi esitetyt huomautukset antavat tietoja mahdollisista virhetyypeistä. Tärkeänä luotettavuuden edellytyksenä on kuitenkin, että arvostelijat ovat harjaantuneita ja tuntevat hyvin arvosteltavat kasvikset. Tässä tutkimuksessa selvimpänä makuvirheenä esiintyi porkkanalla ja salaatilla todettu kitkeryys sekä eräät sivumaut, esim. kellarinmaku. Salaatilla ja porkkanalla esiintyi toisinaan nahistumista, mikä on rakenne- ja ulkonäkövirhe. Tomaatin rakennevirheenä oli joko liian kova ja raaka rakenne tai sitten pehmeneminen. Kypsymisen edistyessä ensinmainittu virhe tavallisesti korjaantuu, mutta pehmeneminen vain pahenee varastoitaessa.

Eräänä vaikeutena aistinvaraisessa arvostelussa onkin ollut se, että tukkukaupan vastaanottovaiheessa tomaatit ovat vielä melko raakoja eivätkä ole aistinvaraisesti arvosteltuina vielä parhaimmillaan. Tomaatin varastointikokeessa todettiin aistinvaraisen laadun joko säilyvän muuttumattomana tai parantuvan 9-13 vrk kuluessa lämpötilasta riippumatta. Olisi hyödyksi, jos aistinvaraista arvostelua voitaisiin kehittää niin, että sen avulla voitaisiin saada ennuste laadun tasosta markkinoinnin myöhemmässä vaiheessa. Tämä saattaa kuitenkin olla vaikeata.

Tässä tutkimuksessa on aistinvaraisessa arvostelussa käytetty Karlsruhen pistearvosteluasteikkoa, joka on kytketty yhteen laatuluokituksen kanssa. Näin meneteltiin siitä syystä, että asteikko saataisiin mahdollisimman varmakäyttöiseksi. Kannattaa pohtia, onko tämä paras mahdollinen ratkaisu. Menettely edellyttää arvostelijoilta perehtymistä monimutkaiseen arviointikaavioon, mutta helpottaa toisaalta yhdenmukaisten tulosten saamista. Menetelmää on kokeiltu tutkimukseen osallistuneiden tukkuliikkeiden laboratorioissa, jotka pitivät sitä käyttökelpoisena. Mikäli laatuluokituksen ja aistinvaraisesti todettavan laadun välillä esiintyisi pahaa ristiriitaisuutta (vrt. Hentschel ja Schuphan 1975), tällainen yhdistetty menetelmä ei ehkä toimisi hyvin. Kuitenkin jos aistinvaraisesti todettavia virheitä esiintyy, paneli joka tapauksessa toteaa ne, ja laatuluokka määräytyy osaksi sen mukaisesti. 
Eräs johtopäätös edellä selostetuista tutkimuksista on, että ne muutamat ominaisuudet, joita on käytetty sisäisen laadun kriteereinä, ovat suuressa määrin toisistaan riippumattomia. Tästä johtuen jokainen niistä on sisäisen laadun takaamiseksi määritettävä erikseen. Jos sisäisen laadun sekä positiiviset että negatiiviset tekijät olisi analyysein varmistettava, tämä on erittäin laaja tehtävä. Nyt tutkituista menetelmistä käyttökelpoisimmilta ja tärkeimmiltä näyttävät aistinvaraisen laadun arvioiminen sekä nitraattipitoisuus.

Edellä selostettu tutkimus koskee ainoastaan kolmea markkinoilla runsaasti esiintyvää kasvista, joiden säilyvyys vaihtelee salaatin lyhyestä porkkanan pitkään. Kullakin kasviksella on omat laatukriteerinsä ja säilyvyysominaisuutensa, joten nyt käytettyjä menetelmiä ei voida aivan sellaisinaan soveltaa muiden kasvisten kohdalla. Erityisesti aistinvaraiselle arvostelulle on jokaista kasvista varten laadittava oma arvostelumenetelmänsä, johon liittyy myös laatuluokittelu. Kaikille kasviksille ei laatuluokitusta liene vielä edes laadittu. Olisi kuitenkin tärkeää, että kasviksien laatukysymyksiä voitaisiin selvittää tarkemmin, koska tämä parantaisi edellytyksiä kasviksien käytön lisäämiselle. Vaikka nyt selostettuja tuloksia ei voitaisikaan vielä lähitulevaisuudessa käyttää kasviksien sisäisen laadun deklarointiin kaupan portaassa, ne saattavat olla hyödyksi kasvistuotannon kehittämisessä laadun arvioinnin apuna.

\section{Tiivistelmä}

Kasviksien sisäiseen laatuun kuuluvat aistinvaraisesti todettavat ominaisuudet ja ravintoarvo sekä turvallisuustekijät. Tässä tutkimuksessa on tutkittu eräiden sisäistä laatua mittaavien menetelmien käyttökelpoisuutta. Näitä menetelmiä on käytetty sitten markkinoilla olevien kasviksien laadun arvioimiseen.

Tutkimuskohteena oli kolme kasvista: salaatti, tomaatti ja porkkana. Kasvikset saatiin tukkuliikkeiltä; joitakin näytteitä hankittiin vähittäiskaupasta tai torilta. Aineisto oli pääasiallisesti kotimaista, vain pieni osa ulkomaista alkuperää.

Pääsarjaan kuului tukkukaupan näytteitä kaikista kolmesta kasviksesta 6 kertaa vuoden aikana. Tomaatin laatua tutkittiin lisäksi torilta hankitulla eri hintaisella tavaralla. Varastointikokeita suoritettiin salaatilla ja tomaatilla.

Laadun arvioinnissa käytettiin aistinvaraista arvostelua (pistearvostelumenetelmä); tutkitut laatuominaisuudet olivat maku, haju, rakenne ja ulkonäkö. Lisäksi arvioitiin laatuluokka.

Analyyttisinä kriteereinä olivat liukoinen kuiva-aine, happopitoisuus, askorbiinihappo sekä nitraattipitoisuus, toisinaan myös painohäviö ja kauppakunnostustappio.

Aistinvarainen arvostelu soveltui parhaiten sisäisen laadun arvioimiseen. Enimmäkseen laatuluokan kaupallinen arviointi sopi yhteen aistinvaraisesti todettavien ominaisuuksien kanssa, mutta toisinaan todettiin kitkerää makua tai muuta virhemakua. Nitraattipitoisuudessa todettiin suuria vaihteluita, jotka olivat laatuluokituksesta riippumattomia. Muut kokeillut menetelmät 
soveltuvat huonommin sisäisen laadun mittaamiseen; niihin voivat vaikuttaa monet eri tekijät. Nyt kokeillut menetelmät voivat olla hyödyksi markkinoitavien kasviksien laatua parannettaessa.

\section{KIRJALLISUUSLUETTELO}

Amerine, M. A., Pangborn, R. M. \& Roessler, E. B. 1965. Principles of sensory evaluation of food. 602 p. New York and London.

ANon. 1970. Maataloushallituksen vahvistamat tuoreitten kasviksien laatuvaatimukset ja lajitteluohjeet. 79 p. Helsinki.

Anon. 1977. Nitrate ion electrode model 93-07. Orion Research, Instruction Manual. 27 p. FrEED, M. 1966. Methods of vitamin assay. p. 294-299. New York-London-Sydney.

Hentschel, H. \& Schuphan, W. 1975. Pflanzenqualität, Erbgut und Umwelt - Vorschläge zur ernährungsbiologischen Aufwertung der Handelsklassen. Deutsche LebensmittelRundschau 71 (8): $277-283$.

Horwirz, W. (Ed.). 1975 a. Official methods of analysis of the association of official analytical chemists. 12th Ed. Publ. Association of Official Analytical Chemists, PO Box 540, Benjamin Franklin Station, Washington, DC 20044; 31.011, p. 566.

- (Ed.) 1975 b. Official methods of analysis of the association of official analytical chemists. 12th Ed. Publ. Association of Official Analytical Chemists, PO Box 540, Benjamin Franklin Station, Washington, DC 20044; 22.060, p. 401.

Kramer, A. \& Twigg, B. A. 1962. Fundamentals of quality control for the food industry. p. 16. Westport, Connecticut.

Paulus, K., Gutschmidt, J. \& Fricker, A. 1969. Karlsruher Bewertungsscheme - Entwicklung, Anwendbarkeit, Modifikationen. Lebensmittel-Wissenschaft u. Technol. $2(6): 132-139$.

Ms received February 21, 1980. 